\title{
Arbuscule Frequency in Grapevine Roots Is More Responsive to Reduction in Photosynthetic Capacity Than to Increased Levels of Shoot Phosphorus
}

\author{
R. Paul Schreiner ${ }^{1}$ and Carolyn F. Scagel \\ USDA-ARS Horticultural Crops Research Laboratory, 3420 Northwest Orchard Avenue, Corvallis, \\ OR 97330
}

\begin{abstract}
AdDitional INDEX wORDs. arbuscular mycorrhizal fungi, foliar fertilizer, root colonization, regulation, shading, Vitis vinifera
Abstract. An interplay between carbon and phosphorus is known to regulate root colonization by arbuscular mycorrhizal fungi (AMF); however, it is unclear whether plant $C$ or plant $P$ status plays a bigger role in controlling the abundance of arbuscules (the primary site of nutrient exchange in AMF symbiosis) in roots. In this study, 'Pinot noir' grapevine (Vitis vinifera) was grown in an unsterilized vineyard soil and colonized by indigenous AMF in two experiments, where photosynthetic capacity (defoliation or shading) and shoot nutrition (foliar fertilizer) were manipulated. Temporal changes in root colonization by AMF and plant growth and nutrition were determined. Foliar fertilizer application increased $P$ and $K$ uptake, but reduced $C u$ uptake in both experiments. Decreasing the photosynthetic capacity of shoots due to defoliation or shading rapidly reduced arbuscules in fine roots (within 7 to 14 days). In contrast a 3-fold increase in shoot $P$ status from foliar fertilizer only reduced arbuscules after a more prolonged time (28 to 56 days). The combination of shading (15\% of full sun) and foliar $P$ application reduced arbuscules more than shading alone within the first month, whereas foliar $P$ use in full sun had no influence on arbuscules within a month. Returning plants to full sun after $\mathbf{2 8}$ days in shade resulted in a resurgence of arbuscules in roots regardless of plant $P$ status. Arbuscules in grapevine roots are regulated by the interaction between plant $C$ and $P$ status, such that high shoot $P$ reduces arbuscule formation or maintenance more when combined with reduced plant photosynthesis. This indicates that grapevines do not reduce AMF nutrient transfer as an immediate response to elevated shoot $P$ as long as plants are maintained in a high light environment.
\end{abstract}

The frequency of arbuscules in root cortical cells has become a common measure in symbiosis research with AMF, as opposed to the traditional measure of root length colonized by any AMF structures (including hyphae and vesicles). Arbuscules are the primary site of nutrient exchange between host plant roots and their fungal partners, although some nutrient exchange might also be associated with other fungal structures in roots such as intercellular hyphae and intracellular coils (Smith and Read, 2008). Arbuscules are known to develop and collapse over a short time span of $\approx 5-7 \mathrm{~d}$ in annual plants (Alexander et al., 1989), and their development involves elaborate coordination, significant resources invested by both partners, and cross-talk between host plants and AMF (Harrison, 2005; Parniske, 2008). Indeed, arbuscules may be the most important site of regulation of the symbiosis by both partners in arbuscular mycorrhizas. Loss of function of the phosphate transporter (PT4) that is expressed in cells with arbuscules and hence P uptake from AMF (Javot et al., 2007) or the impairment of sucrose unloading in roots that supplies $\mathrm{C}$ to the fungi (Baier et al., 2010) both lead to early collapse or senescence of arbuscules. When neither partner obtains what is required to maintain the cost of the partnership, arbuscules are quickly aborted or fail to develop fully. Thus, the frequency of

Received for publication 12 Nov. 2015. Accepted for publication 30 Dec. 2015 We thank Matthew Scott, Jennifer Christie, and Suean Ott for technical assistance.

Mention of trade names or commercial products in this article is solely for the purpose of providing specific information and does not imply recommendation or endorsement by the U.S. Department of Agriculture.

${ }^{1}$ Corresponding author. E-mail: paul.schreiner@ars.usda.gov. arbuscules in roots represents a more immediate status of active exchange or a functional symbiosis, while total AMF colonization in roots may not.

Sugar supply to roots has long been known to positively influence the development of arbuscules (Hayman, 1974), and gene transcripts for sucrose metabolizing enzymes (sucrose synthase and vacuolar invertase believed to increase potential sink strength) have been shown to accumulate in cells harboring arbuscules (Blee and Anderson, 2002). Consistent with the role that $\mathrm{C}$ supply is necessary to support arbuscule formation or maintenance in roots, we have observed that the frequency of arbuscules in grape roots increases dramatically from early summer to midsummer in concert with increasing leaf area and photosynthetic capacity of vines, whereas total AMF colonization in roots does not change (Schreiner, 2005b). Arbuscules in grapevines were also depressed to a greater extent and earlier than was total AMF colonization by ring nematode (Mesocriconema xenoplax) feeding, which was linked to reduced root starch levels (Pinkerton et al., 2004; Schreiner and Pinkerton, 2008). In addition, arbuscules decreased rapidly in grapevine roots in an autumn when high rainfall and low solar radiation levels occurred after fruit harvest, but remained high the following year when the postharvest weather was sunnier (Schreiner, 2005b).

High $\mathrm{P}$ availability in soils or in plants is well known to reduce AMF colonization, and effects of high P supply on AMF colonization are more significant at low irradiance (Daft and El-Giahmi, 1978; Graham et al., 1982; Sanders, 1975; Son and Smith, 1988). Although this interaction between low light levels and high P supply has been linked to lower levels of soluble carbohydrates in roots and root exudates, it is clear that 
C status does not regulate AMF colonization through the same mechanism as high P supply (Breuillin et al., 2010; Ravnskov et al., 2003; Smith and Read, 2008). AMF colonization is often reduced under conditions of high $\mathrm{P}$ status by reducing the spread of the fungus within roots that are already colonized as well as the formation of new infection sites, but arbuscules are not always affected by high P status (Smith and Read, 2008). The mechanisms that govern how plant $\mathrm{P}$ status influences AMF development and arbuscules specifically in roots is an area of intensive investigation, involving the integration of both systemic and local $\mathrm{P}$ sensing pathways and roles for plant hormones (auxins, strigolactones, abscisic acid), P transporters, microRNAs, and other signaling compounds (Carbonnel and Gutjahr, 2014; Gu et al., 2011). Since photosynthate supply to roots acts as a global regulator of $\mathrm{P}$ homeostasis within plants (Hammond and White, 2011; Lin et al., 2014), root carbohydrate supply must interact with other P-sensing mechanisms to influence AMF development (Smith et al., 2011).

Grapevine is highly responsive to AMF when grown under P-limiting conditions, and their fine roots are heavily colonized by AMF, supporting exceptional numbers of arbuscules in many roots (i.e., every single root cortical cell harbored arbuscules in many individual fine roots) (Schreiner, 2005b, 2007). Such precocious levels of arbuscules led us to wonder whether arbuscule lifespan might be significantly longer in grape roots than in annual plants (Alexander et al., 1989) or if grapes have a reduced capacity to regulate arbuscule development as observed in other host plants (Baier et al., 2010; Breuillin et al., 2010). Greater longevity of arbuscules in roots of perennial plants could be related to a more consistent seasonal supply of fixed carbon to roots in perennial compared with annual plants. This might explain why we routinely see very high arbuscule frequency in grapevine roots from field and greenhouse studies.

The purpose of this study was to test how AMF colonization and arbuscules, in particular, respond to manipulating shoot photosynthetic capacity and shoot $\mathrm{P}$ status in grapevine. We examined root colonization patterns after applying treatments to alter photosynthate supply to roots (defoliation or shading) and $\mathrm{P}$ in shoots (foliar fertilizer application). Foliar fertilizer was used here as opposed to soil fertilizer to separate potential direct effects of mineral nutrients on AMF from plant-mediated effects. After showing that arbuscule frequency was more responsive to loss of $\mathrm{C}$ supply than to increased shoot $\mathrm{P}$ using an extreme measure (defoliation), we further examined the interactive effects of light regime (shading vs. full sun) and foliar fertilizer application on AMF colonization and subsequent vine growth and nutrient uptake. We also evaluated how AMF colonization recovered after shaded plants were returned to full sun. Grapevine was previously shown to be heavily dependent on AMF to obtain enough $\mathrm{P}$ to support any biomass gain in the soil used here (Schreiner, 2007; Schreiner and Pinkerton, 2008).

\section{Materials and Methods}

Planting material, soil, ANd Greenhouse conditions. Plants used in both experiments were initially produced from dormant three-node cuttings of 'Pinot noir' Pommard (FPS 91) collected from the Oregon State University, Woodhall Research Vineyard (OSU-WRV) located near Alpine, OR. Cuttings were rooted in sterile vermiculite:perlite, grown for
6-7 weeks in a mist chamber with bottom heat, and then acclimated to the experimental greenhouse for 1 week before transplanting into the experimental soil. For Expt. $1, \approx 50$ cuttings were rooted and transplanted, and for Expt. 2, $\approx 200$ plants were transplanted. The soil used for both experiments was a 1:1 (by volume) mixture of live Jory series silty-clay loam (fine, mixed, active, mesic Xeric Palehumult) collected from OSU-WRV and sterilized coarse sand (Prestress sand mix; Knife River, Corvallis, OR). Available P (Bray 1) in this soil was $13 \mathrm{mg} \cdot \mathrm{kg}^{-1}$. The AMF native to the OSU-WRV Jory soil served as the source of mycorrhizal inoculum. Previously, we isolated spores of at least 10 AMF species from this soil at OSU-WRV, including Scutellospora calospora, Acaulospora laevis, Acaulospora elegans, an unknown Clariodeoglomus species, Rhizophagus intraradices, Glomus mosseae, Sclerocystis rubiformis, and three other unknown Glomus species (Schreiner and Mihara, 2009). For each experiment, the soil mixture was placed in plastic pots $(\approx 2.3 \mathrm{~kg}$ in Expt. 1 in $2-\mathrm{L}$ pots and $\approx 5 \mathrm{~kg}$ in Expt. 2 in 4-L pots) and a single prerooted vine was planted into each pot. Plants were grown in a greenhouse located in Corvallis, OR (lat. $44.568^{\circ} \mathrm{N}$, long. $123.289^{\circ} \mathrm{W}$ ), equipped with supplemental lights provided by $1000-\mathrm{W}$ phosphor-coated metal-halide lamps (General Electric, Fairfield, CT) on a 14-h photoperiod that provided $600 \mu \mathrm{mol} \cdot \mathrm{m}^{-2} \cdot \mathrm{s}^{-1}$ photosynthetically active radiation $(P A R)$ at soil level (used only on cloudy days). Typical midday full sun light levels throughout the entire canopies of vines averaged $\approx 1200 \mu \mathrm{mol} \cdot \mathrm{m}^{-2} \cdot \mathrm{s}^{-1} P A R$. Low and high temperatures in the greenhouse were set at $12 / 25^{\circ} \mathrm{C}$, resulting in actual temperature ranges of $12-20 / 20-30{ }^{\circ} \mathrm{C}$ (night/day).

ExPT. 1. This experiment tested how foliar fertilizer application $(+\mathrm{NPK})$ and defoliation altered AMF colonization in 'Pinot noir' roots over a 4-week period using soil cores to obtain root samples from each vine every $7 \mathrm{~d}$. Vines were grown for 8 weeks after transplanting into the experimental soil and fertilized once per week (soil application) with $200 \mathrm{~mL}$ of a 50\% strength Hoagland's solution (Hoagland and Arnon, 1950). After 8 weeks [T0 (0 d after treatment)], 18 vines of uniform size (based on shoot length) were randomly divided into three treatment groups (control, + NPK, and defoliated) with six plants per treatment.

Containers were placed on the greenhouse bench in a completely random design. The + NPK vines were treated one time at T0 with a foliar application of $100 \mathrm{mM} \mathrm{KH}_{2} \mathrm{PO}_{4}, 100 \mathrm{~mm}$ $\mathrm{NH}_{4} \mathrm{H}_{2} \mathrm{PO}_{4}$ in distilled water by spraying all leaves on each vine until runoff. The soil surface of each pot was covered during application. The defoliated vines had all leaves stripped off (the shoot tip was retained), whereas no leaves were removed from the control vines. All plants were gently misted three to four times per day by hand with distilled water over the next $2 \mathrm{~d}$ (to encourage foliar uptake in the + NPK treatment).

Roots were sampled from each pot every $7 \mathrm{~d}$ for 4 weeks, including the day we initiated treatments (T0, T7, T14, T21, T28). Soil cores (2-cm diameter) were obtained by sampling halfway between the plant stem (center of the pot) and pot sidewall. The location of this core was marked and refilled with experimental soil to avoid sampling in the same location in the future. Roots were washed free from the soil core over a $500-\mu \mathrm{m}$ sieve, blotted dry, and stored in formaldehyde:acetic acid:alcohol (FAA) (1\%:10\%:50\% [by volume]). Root length was determined by gridline intercept method (Newman 1966), and the proportion of root length colonized by AMF structures 
(including hyphae, arbuscules, or vesicles, henceforth referred to as $\%$ AMF colonization) and the proportion of root length with arbuscules (henceforth referred to as \% arbuscules) were determined after clearing and staining with trypan blue and mounting roots on microscope slides as described by Schreiner (2003).

At T28, stems and leaves from each vine were removed, washed in distilled water, and oven dried at $65{ }^{\circ} \mathrm{C}$ for $4-5 \mathrm{~d}$. After obtaining dry weights, nutrient concentrations in leaves (blade + petiole) were determined after grinding to pass through a $425-\mu \mathrm{m}$ sieve. Nitrogen was determined by combustion analysis (LECO, St. Joseph, MI) and P, K, S, Ca, Mg, Mn, $\mathrm{Cu}, \mathrm{B}, \mathrm{Zn}$, and $\mathrm{Fe}$ were determined by inductively coupled plasma optical emission spectrometry (Optima 3000D; Perkin Elmer, Wellesley, MA) after microwave digestion in 70\% $\mathrm{HNO}_{3}$ (Jones and Case, 1990). Reference standard apple (Malus $\times$ domestica) leaves (no. 151, National Institute of Standards and Technology) were analyzed with experimental samples for all procedures.

ExPT. 2. This experiment tested how foliar fertilizer application $(+\mathrm{PK})$ and three light regimes altered AMF colonization in 'Pinot noir' roots over 8 weeks using whole vine destructive harvests every $14 \mathrm{~d}$ (T14, T28, T42, T56). Nitrogen was excluded from the foliar fertilizer used in Expt. 2 to eliminate the possible interactive effect between $\mathrm{N}$ and $\mathrm{P}$ on arbuscule development (Javot et al., 2011). Vines were grown for 5 weeks (35 d) after transplanting into the experimental soil, and fertilized once per week with $400 \mathrm{~mL}$ of a $50 \%$ strength Hoagland's solution. After 5 weeks (T0), 126 vines of uniform size (based on shoot length) were selected and randomly divided into six different treatment groups.

Containers were placed on the greenhouse bench in a randomized block design with three light regimes (full sun for 8 weeks, shade for 8 weeks, and shade/full sun for 4 weeks each) and two foliar fertilization treatments (control and $+\mathrm{PK}$ ). Each treatment combination had six replicates at each of the four destructive harvests. The shade/full sun treatment was not represented in the first two harvests, as this treatment was not started until T28. Therefore, at each of the first two harvests (T14, T28), 12 vines were assessed from each of the full sun and shade treatments $(6+\mathrm{PK}$, and 6 control vines from each light regime). At the last two harvests (T42, T56), another 12 vines were assessed from each of the full sun and shade treatments, and 12 additional vines were also assessed from shade/full sun treatment, for a total of 120 vines in the experiment. Six vines were also destructively harvested at T0, but the data from this initial time point were not used in statistical analysis.

The shade treatment was imposed by moving plants under shadecloth, which reduced incident $P A R$ by $85 \%$ as in Schreiner et al. (2012). Typical middaylight levels throughout the entire canopies of the shade vines averaged $\approx 200$ $\mu \mathrm{mol} \cdot \mathrm{m}^{-2} \cdot \mathrm{s}^{-1} P A R$. At T28, half of the remaining shade plants were moved back to full sun conditions for the shade/full sun treatment vines. The $+\mathrm{PK}$ treatment was applied to half of the vines within each light regime by applying a mixture of $100 \mathrm{~mm}$ $\mathrm{KH}_{2} \mathrm{PO}_{4}$ and $100 \mathrm{~mm} \mathrm{~K} \mathrm{HPO}_{4}$ in distilled water to the leaves one time at T0 as in Expt. 1. Plants in all treatments were misted as in Expt. 1 for the following $2 \mathrm{~d}$ after applying foliar PK.

At T14, T28, T42, T56, six vines from each treatment combination were destructively harvested and separated into shoots (stems and leaves together), wood (original cutting cane), and roots. All roots were washed free from soil, cut into $\approx 2-\mathrm{cm}$ lengths, and a 0.5-g subsample (fresh weight) was randomly removed and stored in FAA to later assess AMF colonization as in Expt. 1. The remaining roots, shoots, and wood tissues were rinsed in distilled water, oven dried, and ground to determine dry matter and nutrient concentrations as in Expt. 1.

DAta ANALYsis. Data were tested for homogeneity of variance using Levene's test and for normality using the KolmogorovSmirnov test. No data transformations were necessary to meet assumptions of analysis of variance (ANOVA). In both experiments, ANOVA effects were considered significant when $P<$ 0.05 . Where applicable, means were separated using Tukey's honestly significant difference test at $P<0.05$. Statistica ${ }^{\circledR}$ software (version 10; Statsoft, Tulsa, OK) was used for all analyses.

For Expt. 1, root length, \% AMF colonization, and \% arbuscules data were analyzed by ANOVA with three treatments (control, defoliated, + NPK) and five sampling times as main effects in a complete factorial design. Leaf dry weight, nutrient concentration, and content data from Expt. 1 were analyzed using a single-factor ANOVA with two treatments (control, + NPK), as no leaves were present on defoliated vines and plants were only destructively harvested on one date. Leaf nutrient content was calculated by multiplying leaf dry weight by the concentration of each nutrient therein (Chapin and Van Cleve, 1989).

Data from Expt. 2 were analyzed by separate ANOVAs for each harvest date using two foliar treatments (control, + PK)

Table 1. Effect of foliar NPK application on leaf nutrient concentrations and contents in potted 'Pinot noir' grapevine $28 \mathrm{~d}$ after treatments were imposed in Expt. 1.

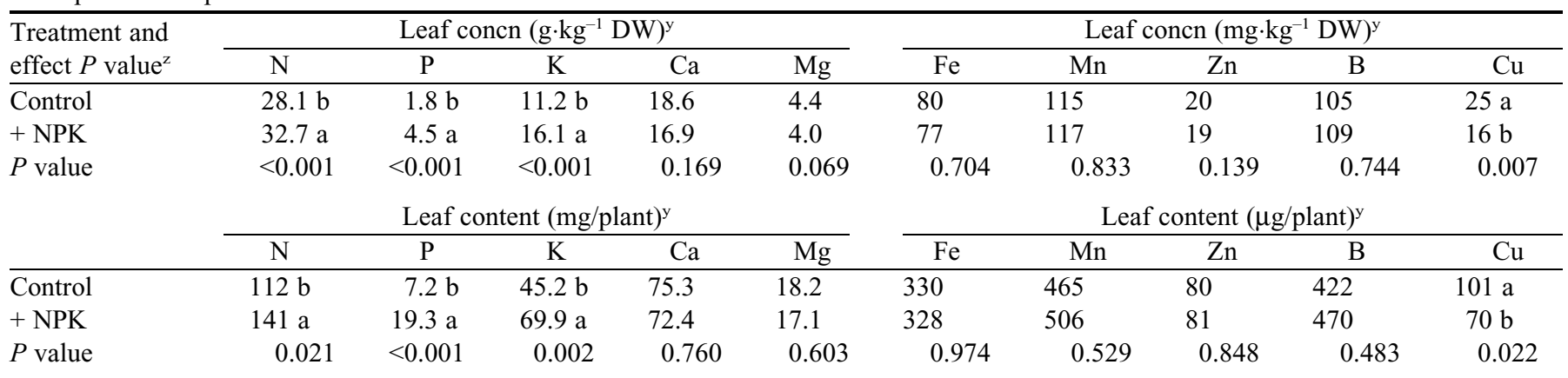

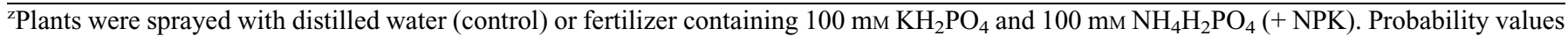
for effect of foliar fertilizer treatment obtained from analysis of variance.

${ }^{y}$ Means $(n=6)$ within a column and response variable followed by a different letter indicate significant difference based on Tukey's honestly significant difference test at $95 \%$ confidence. 
and either two light treatments (T14, T28) or three light treatments (T42, T56) in complete factorial designs. Total nutrient uptake between specific sampling dates (T0 and T14; T14 and T28; T28 and T42, T42, and T56) was obtained by subtracting the mean value of nutrient content from each respective treatment from the prior sampling point from the new values obtained at successive times. Total nutrient uptake between $\mathrm{T} 0$ and $\mathrm{T} 56$ was calculated by subtracting the mean nutrient content from the initial vines harvested at $\mathrm{T} 0$ from the final values at T56.

\section{Results}

ExPT. 1. Foliar application of NPK increased N, P, and K concentrations and contents in leaves 4 weeks (T28) after treatments were initiated (Table 1). Compared with the untreated control, foliar fertilization increased leaf $\mathrm{N}, \mathrm{P}$, and $\mathrm{K}$ concentrations by $16 \%, 150 \%$, and $43 \%$, respectively. Foliar NPK decreased leaf $\mathrm{Cu}$ concentrations and contents at T28 compared with control vines, but no other nutrient (concentration or content) was altered by foliar fertilization. At the end of Expt. 1 (T28), shoot dry mass was lowest in defoliated vines $(1.61 \mathrm{~g})$ and did not differ between controls $(6.79 \mathrm{~g})$ and + NPK vines $(7.65 \mathrm{~g})$. Leaf dry mass also did not differ between controls $(4.02 \mathrm{~g})$ and + NPK vines (4.32) at T28.

Defoliation altered root growth (fine root length) and AMF colonization in fine roots and foliar NPK application only altered AMF colonization (Fig. 1). Fine root length of control and + NPK vines increased from T0 to T28, whereas root length was static in defoliated vines (Fig. 1A). Compared with the control, foliar fertilization decreased $\%$ AMF colonization (Fig. 1B) and \% arbuscules (Fig. 1C) only after 28 d. In contrast, defoliation suppressed $\%$ arbuscules within $7 \mathrm{~d}$ after treatment and $\%$ arbuscules remained lower in defoliated plants than controls for the remainder of the experiment. The control and defoliated plants had similar \% AMF colonization.

EXPT. 2. Foliar application of PK $(+P K)$ increased shoot $P$ concentrations at all sampling dates, but only increased root $\mathrm{P}$ concentrations at T14 (Table 2). Both shoot and root K concentrations were greater in $+\mathrm{PK}$ vines than control vines at all dates (Table 2). In general, foliar PK use boosted shoot P concentrations to a greater degree than shoot $\mathrm{K}$ concentrations. For example, shoot $\mathrm{P}$ was $176 \%$ greater in $+\mathrm{PK}$ vines than in controls at T14, whereas shoot K was only $53 \%$ greater at T14. The impact of foliar PK application on root P and K did not mirror effects on shoots. For example, root $\mathrm{P}$ concentration was $15 \%$ greater in $+\mathrm{PK}$ vines than controls at T14, whereas root $\mathrm{K}$ concentration was $30 \%$ greater at T14. At later harvest dates, + $\mathrm{PK}$ vines no longer had increased root $\mathrm{P}$ concentrations, yet root $\mathrm{K}$ concentrations remained greater in $+\mathrm{PK}$ vines than the controls for the whole experiment.

Foliar PK did not alter shoot or root $\mathrm{N}$ concentrations at any time (Table 2). However, in the $+\mathrm{PK}$ vines concentrations of $\mathrm{Cu}$ were reduced in shoots at T42 (13\%) and T56 (25\%), and in roots at T56 (33\%) compared with the controls (data not shown). Foliar PK also altered the concentration of $\mathrm{Mg}, \mathrm{Mn}$, $\mathrm{B}$, and $\mathrm{S}$ at one or more dates in either shoots or roots, but these effects were generally small (all below $10 \%$ difference compared with controls), inconsistent between shoots and roots and were only apparent at a single harvest date (data not shown).

Light treatment had a significant effect on the concentration of every nutrient examined in shoots and roots for at least one

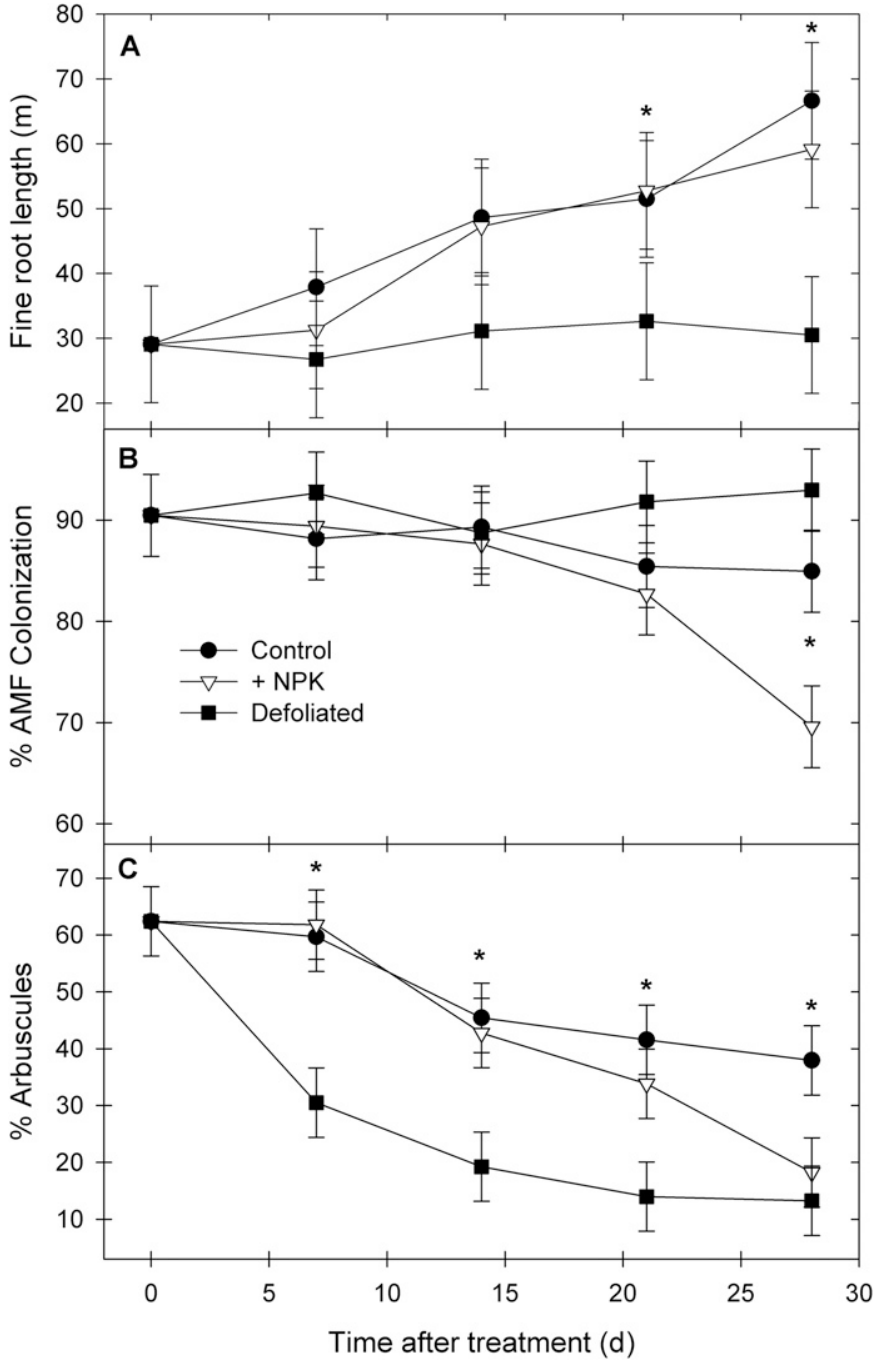

Fig. 1. Effect of (A) defoliation or foliar NPK fertilization on root length, (B) \% AMF (arbuscular mycorrhizal fungi) colonization by any fungal structure, and (C) \% arbuscules in potted 'Pinot noir' grapevine during $28 \mathrm{~d}$ after treatments were applied in Expt. 1. Plants were sprayed with distilled water (control) or

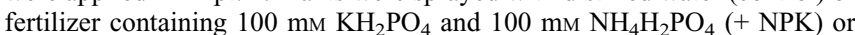
were defoliated (defoliated) at T0. Symbols representing means and error bars are $\pm 95 \%$ least significant difference obtained from analysis of variance. $\mathrm{A}^{*}$ at a given sampling time indicates a significant treatment effect $(P<0.05)$.

sampling date (data not shown). In all cases except for root $\mathrm{P}$ concentrations, shade vines had greater nutrient concentrations compared with full sun vines (dilution effect with growth) and similar or greater concentrations as compared with shade/full sun vines. Root $\mathrm{P}$ concentrations, however, were lower in shade vines at T14 (21\% lower), T28 (16\% lower), and T42 (15\% lower) than levels in full sun or shade/full sun vines. Foliar PK had a similar effect on shoot and root nutrient concentrations in all light treatments $(P>0.05)$.

Percent AMF colonization was altered by light treatment at all dates (T14-T56) and by foliar fertilizer at the last two sampling dates (Fig. 2A and B). The effect of foliar PK on AMF colonization was similar among light treatments. Shade vines had the greatest \% AMF colonization at all dates (Fig. 2A). Compared with controls, \% AMF colonization was lower in the + PK vines at T42 and T56 (Fig. 2B). Percent arbuscules was altered by both light and foliar PK treatments at all dates and the 
Table 2. Main effect of foliar PK application on shoot and root N, P, and K concentrations in 'Pinot noir' grapevine 14, 28, 42, and $56 \mathrm{~d}$ after fertilizer was applied in Expt. 2.

\begin{tabular}{|c|c|c|c|c|c|c|}
\hline \multirow{2}{*}{$\begin{array}{l}\text { Date, treatment, and } \\
\text { effect } P \text { value }\end{array}$} & \multicolumn{3}{|c|}{ Shoot concn $\left(\mathrm{g} \cdot \mathrm{kg}^{-1} \mathrm{DW}\right)^{\mathrm{y}}$} & \multicolumn{3}{|c|}{ Root concn $\left(\mathrm{g} \cdot \mathrm{kg}^{-1} \mathrm{DW}\right)^{\mathrm{y}}$} \\
\hline & $\mathrm{N}$ & $\mathrm{P}$ & $\mathrm{K}$ & $\mathrm{N}$ & $\mathrm{P}$ & $\mathrm{K}$ \\
\hline \multicolumn{7}{|l|}{$\mathrm{T} 14 \mathrm{~d}$} \\
\hline Control & 25.8 & $1.61 \mathrm{~b}$ & $14.4 \mathrm{~b}$ & 19.9 & $1.39 \mathrm{~b}$ & $18.6 \mathrm{~b}$ \\
\hline$+\mathrm{PK}$ & 26.2 & $4.45 \mathrm{a}$ & $22.1 \mathrm{a}$ & 20.4 & $1.60 \mathrm{a}$ & $24.2 \mathrm{a}$ \\
\hline$P$ value & 0.614 & $<0.001$ & $<0.001$ & 0.401 & 0.018 & $<0.001$ \\
\hline \multicolumn{7}{|l|}{$\mathrm{T} 28 \mathrm{~d}$} \\
\hline Control & 23.6 & $1.64 \mathrm{~b}$ & $13.6 \mathrm{~b}$ & 16.1 & 1.29 & $17.0 \mathrm{~b}$ \\
\hline$+\mathrm{PK}$ & 24.1 & $4.49 \mathrm{a}$ & $22.5 \mathrm{a}$ & 16.7 & 1.37 & $19.1 \mathrm{a}$ \\
\hline$P$ value & 0.396 & $<0.001$ & $<0.001$ & 0.274 & 0.091 & 0.016 \\
\hline \multicolumn{7}{|l|}{$\mathrm{T} 42 \mathrm{~d}$} \\
\hline Control & 22.2 & $1.39 \mathrm{~b}$ & $13.3 \mathrm{~b}$ & 15.3 & 1.30 & $16.8 \mathrm{~b}$ \\
\hline$+\mathrm{PK}$ & 21.7 & $3.20 \mathrm{a}$ & $19.0 \mathrm{a}$ & 15.4 & 1.38 & $18.7 \mathrm{a}$ \\
\hline$P$ value & 0.329 & $<0.001$ & $<0.001$ & 0.970 & 0.074 & 0.022 \\
\hline \multicolumn{7}{|l|}{ T56 d } \\
\hline Control & 21.2 & $1.40 \mathrm{~b}$ & $13.0 \mathrm{~b}$ & 15.0 & 1.34 & $17.1 \mathrm{~b}$ \\
\hline$+\mathrm{PK}$ & 20.4 & $2.25 \mathrm{a}$ & $14.8 \mathrm{a}$ & 14.9 & 1.39 & $19.2 \mathrm{a}$ \\
\hline$P$ value & 0.469 & $<0.001$ & 0.002 & 0.783 & 0.336 & 0.031 \\
\hline
\end{tabular}

zPlants were sprayed with distilled water (control) or fertilizer containing $100 \mathrm{mM} \mathrm{KH}_{2} \mathrm{PO}_{4}$ and $100 \mathrm{~mm} \mathrm{~K}_{2} \mathrm{HPO}_{4}$ (+ PK) and harvested 14 (T14), 28 (T28), 42 (T42), and 56 (T56) d after treatment. Probability values for effect of foliar fertilizer treatment obtained from analysis of variance.

${ }^{\mathrm{y}}$ Means $(n=6)$ within a column and harvest date followed by a different letter indicate significant difference based on Tukey's honestly significant difference test at 95\% confidence. fertilizer had an immediate impact on shoot $\mathrm{P}$, increasing shoot $\mathrm{P}$ content by 3 -fold at T14, and resulted in + PK vines having a much greater shoot $\mathrm{P}$ content than the controls throughout the remainder of the experiment (Fig. 4B). At T42, shoot $\mathrm{P}$ content was lower in shade vines than full sun vines, whereas the shade/full sun vines did not differ from either extreme. At T56, shade vines still had lower shoot $P$ content than controls, but $\mathrm{P}$ content was similar in full sun and shade/full sun vines (Fig. 4A). Similar to root biomass, root $\mathrm{P}$ content was greatest in full sun vines, intermediate in shade/full sun vines, and lowest in shade vines (Fig. 4C). Foliar fertilizer only altered root $\mathrm{P}$ content at T42 by decreasing root $\mathrm{P}$ content in full sun vines but not in shade or shade/full sun vines.

Both light treatment and foliar PK altered total vine $\mathrm{P}$ and $\mathrm{K}$ contents, and uptake of $\mathrm{P}$ and $\mathrm{K}$ between sampling times (Table 3). In

effect of foliar PK application on \% arbuscules differed among light treatments $(P<0.05)$ at T14 and T28 (Fig. 2C). During the first $28 \mathrm{~d}, \%$ arbuscules was lower in shade vines compared with full sun vines and reduced further by the combination of shade and + PK. In contrast, foliar PK had no influence on $\%$ arbuscules in full sun vines at T14 and T28. At the last two sampling dates (T42 and T56), shade vines still had the lowest $\%$ arbuscules, but $\%$ arbuscules in the shade/full sun treatment had recovered to a level similar as the full sun treatment by T42. The development of new arbuscules in response to placing shade/full sun vines back into full sunlight occurred in both + $\mathrm{PK}$ and control vines to a similar extent, although $+\mathrm{PK}$ vines still had lower \% arbuscules than control vines in the shade/full sun light treatments.

Light treatment had a greater influence on vine biomass accumulation than foliar fertilizer (Fig. 3). Foliar PK had no influence on aboveground biomass accumulation $(P>0.05)$, while full sun vines had greater shoot biomass than shade vines at all sampling dates (Fig. 3A and B). Shoot mass in the shade/ full sun vines caught up to the full sun vines by T42 and did not differ from full sun vines at T56 (Fig. 3A). The effect of light treatment on wood biomass lagged behind biomass changes expressed in shoots, such that full sun vines did not have greater wood biomass than the shade vines until T28, and wood biomass of the shade/full sun vines never caught up to full sun vine values by T56 (Fig. 3B). In general, root biomass was greatest in full sun vines, intermediate in shade/full sun vines (after their return to full light), and lowest in shade vines (Fig. 3C.). Foliar PK only altered root biomass at T28 and T42. Root biomass in + PK vines was less than controls at T28 in both full sun and shade vines, and at T42 root biomass in + PK plants was only less than control vines in full sun.

Shoot $\mathrm{P}$ content was altered by both light and foliar PK treatments and the effect of foliar fertilizer on shoot $\mathrm{P}$ occurred earlier than that of the light treatment (Fig. 4A and B). Foliar general, shade vines had lower $\mathrm{P}$ and $\mathrm{K}$ contents and the least $\mathrm{P}$ and $\mathrm{K}$ uptake between harvests. Moving plants from shade back to full sunlight increased vine $P$ and $K$ content, although the shade/full sun vines had less vine $P$ than full sun vines at T42 and T56 and less vine $\mathrm{K}$ at T42. Uptake of $\mathrm{P}$ and $\mathrm{K}$ between harvests was similar in full sun or shade/full sun vines. In + PK vines, vine $\mathrm{P}$ and $\mathrm{K}$ content was greater than the control vines, but foliar PK only had greater uptake of $\mathrm{P}$ and $\mathrm{K}$ than controls before the first harvest.

The effects of light treatment on total vine $\mathrm{P}$ and $\mathrm{K}$ uptake over the entire growth period (T0-T56) were similar to the effects of light on uptake of other nutrients (data not shown). Uptake of every nutrient was greatest in full sun vines, intermediate in shade/full sun vines, and lowest in shade vines. In some cases, nutrient uptake in the shade/full sun vines did not differ from either the shade or full sun treatments, but the shade vines always had lower uptake than full sun vines. Foliar PK only altered the total uptake of one nutrient other than $\mathrm{P}$ and $\mathrm{K}$. Total vine $\mathrm{Cu}$ in the control vines $(117 \mu \mathrm{g})$ was $23 \%$ greater than in + PK vines $(90 \mu \mathrm{g} ; P<0.001)$.

\section{Discussion}

The key finding in this investigation was that defoliation or shading reduced arbuscules in roots of grapevine more rapidly than high shoot $\mathrm{P}$ status. Indeed, boosting $\mathrm{P}$ status by $\approx 3$-fold via foliar fertilization only reduced arbuscules after a prolonged period of time or when combined with low light levels. Arbuscules were reduced by limiting photosynthate supply to roots, within $7 \mathrm{~d}$ after defoliation in Expt. 1 and within $14 \mathrm{~d}$ after shading was applied in Expt. 2. Whereas, when vines were grown in full sun, foliar $\mathrm{P}$ application only reduced $\%$ arbuscules simultaneously with \% AMF colonization after $28 \mathrm{~d}$ in Expt. 1 and after $42 \mathrm{~d}$ in Expt. 2. Our findings indicate also that arbuscules in fine roots of grapevines appear to be 


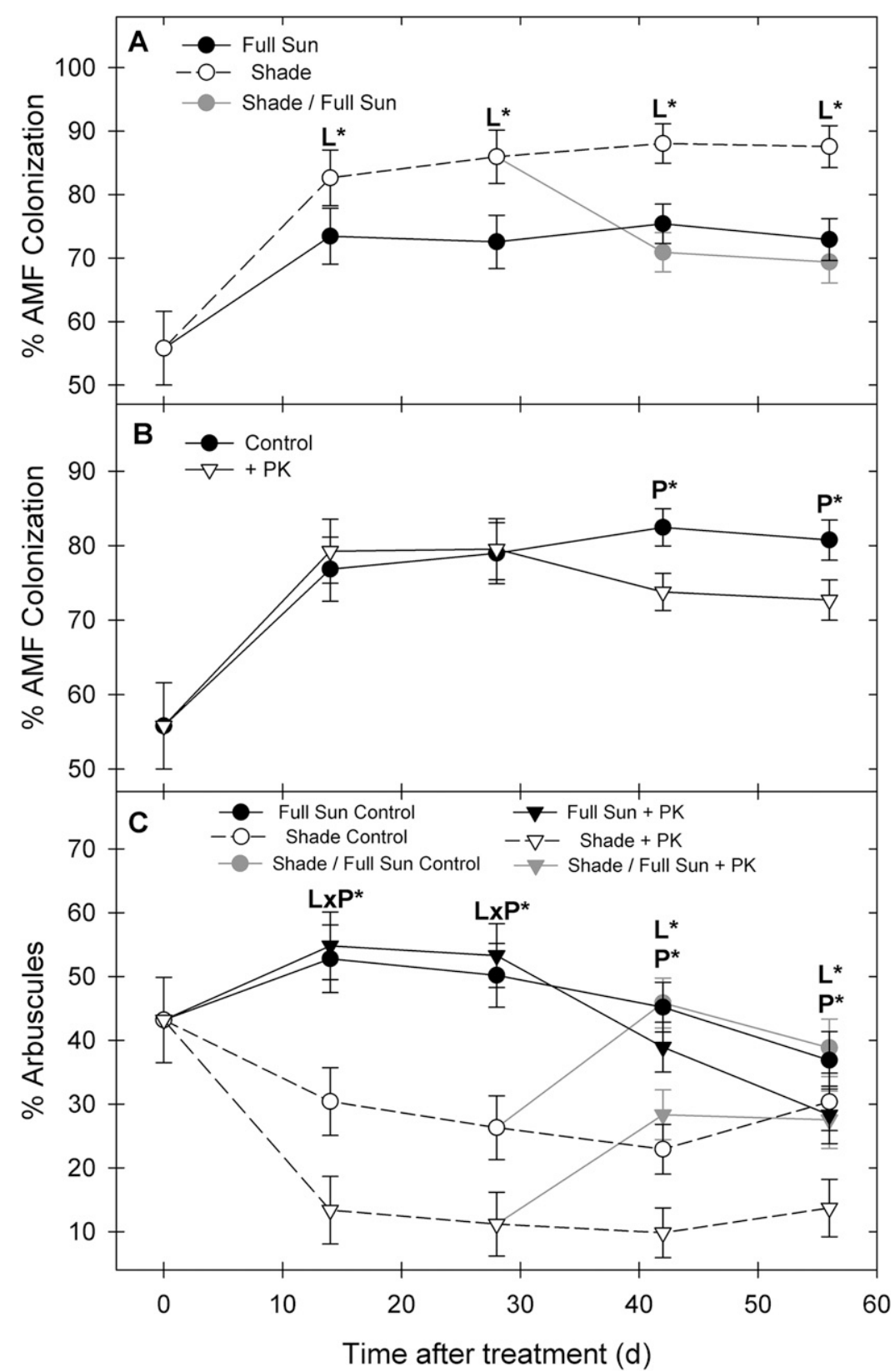

Fig. 2. Main effects of (A) light treatment and (B) foliar PK treatment on \% AMF (arbuscular mycorrhizal fungi) colonization by any fungal structure, and the interactive effect of light and foliar PK treatments on (C) \% arbuscules in potted 'Pinot noir' grapevine during $56 \mathrm{~d}$ in Expt. 2. Plants were sprayed with distilled water (control) or fertilizer containing $100 \mathrm{~mm} \mathrm{KH}_{2} \mathrm{PO}_{4}$ and $100 \mathrm{~mm}$ $\mathrm{K}_{2} \mathrm{HPO}_{4}(+\mathrm{PK})$ at T0 and grown in full sunlight (full sun) or $15 \%$ of full sunlight (shade). On T28, half of the plants grown in $15 \%$ sunlight were moved to full sunlight conditions (shade/full sun) for the remainder of the experiment. Symbols representing means and error bars are $\pm 95 \%$ least significant difference obtained from analysis of variance. An $\mathrm{L}^{*}$ above the highest value symbol at a given sampling time indicates a significant main effect $(P<0.05)$ of light treatment, a $\mathrm{P}^{*}$ indicates a significant main effect $(P<0.05)$ of foliar PK treatment, and an LxP* indicates a significant interaction $(P<0.01)$ between light and foliar PK treatments.

short-lived as known for numerous annual plants (Alexander et al., 1989; Baier et al., 2010; Javot et al., 2007) ruling out the likelihood that arbuscules have a distinctly longer lifespan in grapevines vs. annual plants.

Early studies on regulation of AMF colonization did not report effects on $\%$ arbuscules, so it is difficult to conclude from this literature if arbuscules were more sensitive to light levels and host plant $\mathrm{P}$ status than was \% AMF colonization (Daft and El-Giahmi, 1978; Graham et al., 1982; Sanders, 1975; Smith and Read, 2008; Son and Smith, 1988). Although not quantified, Sanders (1975) noted that arbuscules decreased in roots of onion (Allium cepa) supplied with foliar $\mathrm{P}$ injected into (hollow) leaves, and Hayman (1974) noted that plants under high light had larger-sized arbuscules than plants under low light. A similar reduction in \% arbuscules in response to $\mathrm{P}$ addition at low light, but not at high light was recently reported in roots of a perennial forb (Ligularia virgaurea) grown in mesocosms (Shi et al., 2014), although in that study \% AMF colonization was reduced by $\mathrm{P}$ addition in both high and low light conditions. These findings and our results from Expt. 2 indicate that greater $\mathrm{C}$ supply to roots in a high light environment overrides the $\mathrm{P}$ suppression of arbuscules for a significant amount of time. Indeed, recent studies focused on manipulating sugar supply to roots clearly show that photosynthate supply to roots is a key regulator of arbuscule formation and degradation (Baier et al., 2010; Blee and Anderson, 2002; Gaude et al., 2012).

It is clear that increased sucrose delivery to roots plays a significant role in activating the overall P-starvation response in plants (Hammond and White, 2011) and that sucrose is a global regulator of AMF symbiosis interacting with other P-sensing signals and plant hormones (Gutjahr, 2014; Smith et al., 2011). Enhanced sucrose loading in the phloem was recently shown to upregulate more than $70 \%$ of the known $\mathrm{P}$ starvation genes in roots of Arabidopsis thaliana even when plants had adequate P (Lei et al., 2011). In addition, Liu et al. (2010) used partial shading to examine the $\mathrm{P}$ starvation response in bean roots and found that shading half of the shoot reduced the ability of shoot $\mathrm{P}$ to repress root $\mathrm{P}$ starvation responses. Our finding that arbuscule frequency was reduced by boosting $\mathrm{P}$ status only in plants grown under low light is consistent with the global regulator role of shoot-derived sucrose acting as an overall modulator of plant P homeostasis. The increase in plant P status in Expt. 2 (nearly exclusively in the shoot) quickly repressed arbuscules only in roots of shaded plants that were also $\mathrm{C}$ limited. The same level of shading as employed here in Expt. 2 was previously shown to reduce root sugar concentrations in young 'Pinot noir' roots by $\approx 60 \%$ and the total content of root nonstructural carbohydrates in roots by $\approx 75 \%$ (Schreiner et al., 2012). Similar findings are known from other plants (Nagel et al., 2006).

Arbuscules in grapevine roots respond fairly rapidly to changing light conditions indicating a high sensitivity of 


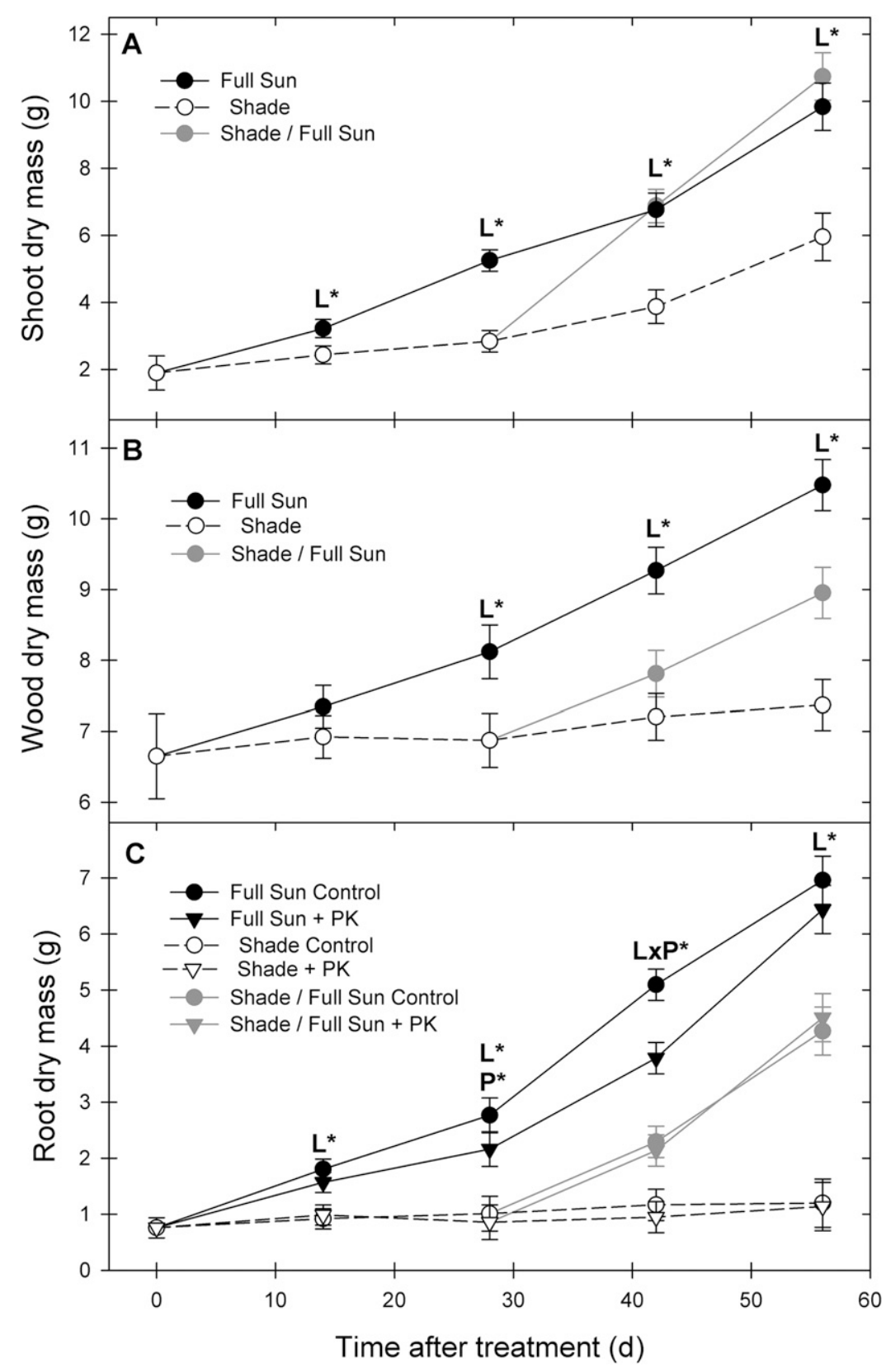

Fig. 3. Main effect of light treatment on (A) shoot dry mass and (B) wood dry mass, and the interactive effect of light and foliar PK treatments on $(\mathbf{C})$ root dry mass in potted 'Pinot noir' grapevine during $56 \mathrm{~d}$ in Expt. 2. Symbols and annotations are the same as Fig. 2.

arbuscules to photosynthate supply. Percent arbuscules rose to full sun levels after switching the shade plants back to full sun in Expt. 2. This occurred in both the control and + PK vines that had luxury levels of shoot P. This reversal in arbuscule frequency indicates that photosynthate supply is a stronger stimulator of arbuscules than high $\mathrm{P}$ status is a repressor of arbuscules. The increase of arbuscules in roots upon return to high light was associated with a return in $\mathrm{P}$ uptake to the same rate as the vines kept in full sun, whereas $P$ uptake in the vines maintained under shade remained low. We are confident that this renewed $\mathrm{P}$ uptake occurred via the mycorrhizal pathway (and not via direct root uptake), as two previous studies showed that nonmycorrhizal 'Pinot noir' grapevines grown in this soil were unable to obtain enough $P$ to even begin growing (Schreiner, 2007; Schreiner and Pinkerton, 2008). In this specific plant-soil system, all (or nearly all) P uptake by 'Pinot noir' can be attributed to AMF. 'Pinot noir', or perhaps this particular clone, appears to lack effective root $\mathrm{P}$ transporters that function at very low soil $\mathrm{P}$ levels encountered in this soil.

Percent AMF colonization in grapevine roots is not as sensitive to changes in light and plant $\mathrm{P}$ status as is \% arbuscules. The effects of reduced light intensity on \% AMF colonization are well known (Smith and Read, 2008), although in Expt. 2 the shaded plants actually had greater \% AMF colonization than full sun vines, a response opposite from most reports. We suspect that this effect on $\%$ AMF colonization was most likely due to differences in root growth. Shading restricted root growth thus vines in shade maintained preshade AMF colonization levels. In contrast, root growth was greater in full sun vines leading to lower \% AMF colonization during our study due to a dilution effect. An interactive effect of low light and high $\mathrm{P}$ status in reducing \% AMF colonization in roots is also well known (Graham et al., 1982; Hayman, 1974; Son and Smith, 1988). However, the impact of defoliation or shading and the interactive effect of shading and high shoot $\mathrm{P}$ status on AMF in this study were quickly expressed in arbuscules while their impact on \% AMF colonization was smaller and developed later.

The divergent responses of \% AMF colonization vs. \% arbuscules reported here suggests that regulation of the AMF symbiosis by plant $\mathrm{P}$ and $\mathrm{C}$ differs fundamentally between arbuscules and other fungal structures in roots. Regulation by high $\mathrm{P}$ status may largely limit future spread of fungus (both internal spread and new entries) thus slowly reducing the proportion of roots colonized by AMF as roots continue to grow, while regulation resulting from changes in $\mathrm{C}$ supply to roots allows for a rapid response at the arbuscule interface. This difference would allow plants to better protect carbohydrate reserves, such that plants do not share fixed $\mathrm{C}$ with $\mathrm{AMF}$ when in short supply, but are willing to share $C$ and maintain $P$ uptake via the mycorrhizal pathway for a longer period of time when $\mathrm{C}$ is abundant even if plant $\mathrm{P}$ status is high. This response would ensure that a continued supply of $\mathrm{P}$ is maintained to boost reserves of $\mathrm{P}$ before shutting down AMF $\mathrm{P}$ transfer, as subsequent rebuilding of the $\mathrm{P}$ uptake pathway is potentially costly. Alternatively, the more sluggish regulation of arbuscules by high $\mathrm{P}$ status vs. low $\mathrm{C}$ status may ensure that the uptake of other nutrients, particularly N, is not suppressed. For example, the early collapse of arbuscules in Medicago truncatula PT4 mutants (that cannot transport $\mathrm{P}$ from AMF) does not occur if plant $\mathrm{N}$ is also deprived (Javot et al., 2011), indicating that both 


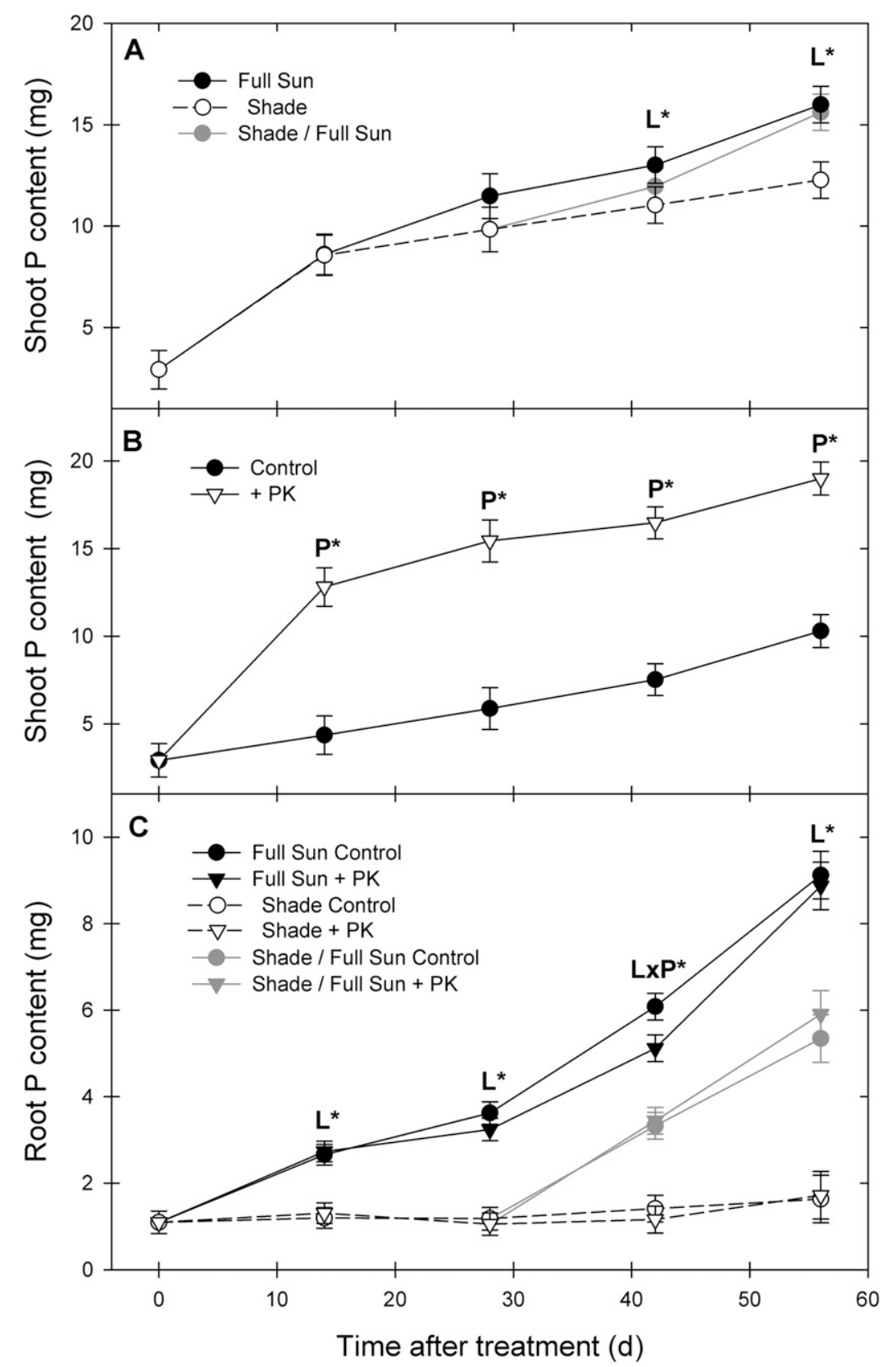

Fig. 4. Main effect of (A) light treatment and (B) foliar PK treatment on shoot $P$ content, and the interactive effect of light and foliar PK treatments on $(\mathbf{C})$ root $\mathrm{P}$ content in potted 'Pinot noir' grapevine during $56 \mathrm{~d}$ in Expt. 2. Symbols and annotations are the same as Fig. 2.

system where two plants shared a common AMF mycelial network (Fellbaum et al., 2014). Similarly, both low N and low $P$ together induced a greater receptiveness of plants to facilitate AMF symbiosis and expression of genes involved in symbiotic $\mathrm{P}$ transfer than low P alone (Bonneau et al., 2013). While AMF have been shown to increase overall $\mathrm{N}$ uptake by grapevines in a few cases, their impact on $\mathrm{P}$ uptake has been more consistent and of far greater magnitude (Schreiner, 2005a, 2007).

The application of foliar $\mathrm{P}$ fertilizer reduced $\mathrm{Cu}$ uptake in both experiments here but did not affect the uptake of any other nutrient not included in the foliar spray. AMF are known to improve $\mathrm{Cu}$ uptake by grapevines when compared with nonmycorrhizal vines (Petgen et al., 1998; Schreiner, 2007). Copper transporters are known to be upregulated in mycorrhizal roots (Tamayo et al., 2014) and specifically in cells harboring arbuscules (Gaude et al., 2012). Foliar P application also reduced \% arbuscules in roots, without affecting \% AMF colonization in one of two 'Pinot noir' vineyards (Schreiner, 2010) similar to findings here in potted vines. However, we did not detect lower vine $\mathrm{Cu}$ status in that study, possibly because we measured leaf and petiole nutrient concentrations but did not determine whole vine copper uptake. In other regions where soil $\mathrm{Cu}$ availability is more limiting (such as alkaline soils), the impairment in $\mathrm{Cu}$ uptake after applying $\mathrm{P}$ could be a significant concern.

Another interesting finding in our study was that the high vine $\mathrm{P}$ status resulting from foliar $\mathrm{P}$ application did not reduce subsequent $\mathrm{P}$ uptake. The large increase in shoot $\mathrm{P}$ in Expt. 2 did not reduce the rate of $\mathrm{P}$ uptake over the following $56 \mathrm{~d}$. Uptake and metabolism of $\mathrm{P}$ is an energy-intensive process and in annual plants, high plant $\mathrm{P}$ status decreases subsequent $\mathrm{P}$ uptake in response to signals from the shoot (Lin et al., 2014). Regulation of $\mathrm{P}$ uptake in perennial plants may differ from annuals, particularly in grapevines, where early summer $\mathrm{P}$ levels in

$\mathrm{N}$ and $\mathrm{P}$ transfer from $\mathrm{AMF}$ (and plant $\mathrm{N}$ and $\mathrm{P}$ status) influence arbuscule maintenance. A role for $\mathrm{N}$ regulation might be inferred also from our finding here that arbuscules were reduced in response to foliar fertilizer more quickly in Expt. 1 (28 d) than Expt. 2 (42 d) because the foliar spray contained $\mathrm{N}$ only in Expt. 1. However, other factors that differed between these experiments including the age and size of the vines when treatments began and greenhouse conditions might also explain that result. Further work to understand how $\mathrm{C}, \mathrm{N}$, and $\mathrm{P}$ interact in regulating arbuscules and other AMF structures in roots is warranted, given that more $\mathrm{N}$ and $\mathrm{P}$ were each shown to be delivered by AMF to the plant that was maintained at a higher light level than a neighboring plant that was shaded in a model shoots are quite high, yet arbuscules in roots increase dramatically at this time (Schreiner, 2005b). This may indicate that grapevines and possibly other perennials exert less control over AMF partners and/or have other $\mathrm{P}$ starvation strategies than those described in annuals (Rennenberg and Herschback, 2013). In addition, the large increase in shoot P in Expt. 2 in response to foliar fertilizer only increased root $\mathrm{P}$ concentrations by a small amount 2 weeks after application and not thereafter. This suggests that $\mathrm{P}$ in shoots is generally not shared with roots in grapevines during the period of active shoot growth and that new root $\mathrm{P}$ requirements continued to rely on mycorrhizal uptake from soil. Potassium, however, was shared more liberally with roots than was $\mathrm{P}$ in Expt. 2. Root $\mathrm{K}$ concentrations 
Table 3. Main effects of light treatment and foliar PK application on total vine $\mathrm{P}$ and $\mathrm{K}$ content and net $\mathrm{P}$ and $\mathrm{K}$ uptake between sampling dates in potted 'Pinot noir' grapevine in Expt. 2.

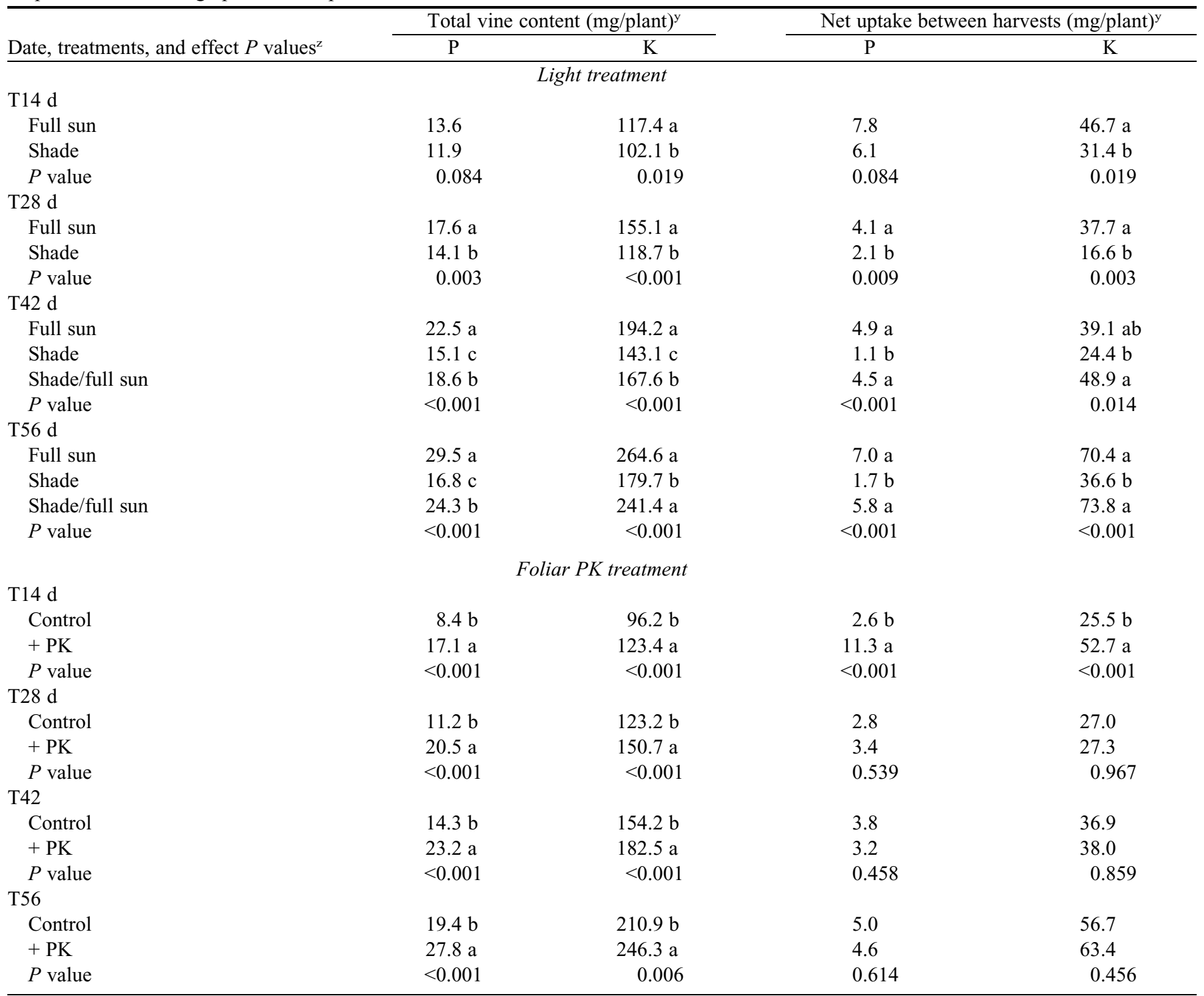

zPlants were harvested 14 (T14), 28 (T28), 42 (T42), and 56 (T56) d after foliar treatment. Plants were grown in full sun or shade (15\% incident photosynthetically active radiation) for $28 \mathrm{~d}$. On T28, half of the plants grown in shade were moved to full sun conditions (shade/full sun) for the remainder of the experiment. Probability values for main effects of foliar fertilizer treatment and light treatment obtained from analysis of variance.

${ }^{\mathrm{y}}$ Means $(n=6)$ within a column for each harvest date and main effect followed by a different letter indicate significant difference based on Tukey's honestly significant difference test at $95 \%$ confidence.

were higher at all times after application of foliar fertilizer. Although, similar to $\mathrm{P}$, whole vine $\mathrm{K}$ uptake was only greater in foliar fertilized vines immediately after application (14 d). Because $\mathrm{K}$ concentrations increased in roots and shoots in response to foliar fertilizer, we cannot rule out the possibility that $\mathrm{K}$ may have played a role also in depressing arbuscules in roots. In reviewing the literature, we could find no studies that have shown an impact of plant K status on arbuscule frequency in roots. A role for $\mathrm{K}$ in regulating AMF is possible given that reduced $\mathrm{C}$ supply to transformed root-AMF dual cultures resulted in the accumulation of both $\mathrm{P}$ and $\mathrm{K}$ in fungal tissues indicating reduced symbiotic delivery of $\mathrm{P}$ and $\mathrm{K}$ to roots under lower C status (Hammer et al., 2011). Lower levels of root colonization by AMF (but not arbuscules specifically) were also weakly correlated with higher K soils in a survey of 45 vineyards in Greece (Karagiannidis and Nikolaou, 1999). However, we are not convinced that $\mathrm{K}$ played a significant role in suppressing arbuscules in this study because $\mathrm{K}$ concentrations in both roots and shoots were already quite high $[>13$ $\mathrm{mg} \cdot \mathrm{kg}^{-1}$ dry weight (DW)] in the control vines that received no foliar fertilizer (Schreiner et al., 2013). Whereas, P concentrations in roots and shoots of the control vines were relatively low $(<1.7$ $\left.\mathrm{mg} \cdot \mathrm{kg}^{-1} \mathrm{DW}\right)$. Foliar fertilizer also boosted shoot $\mathrm{P}$ concentrations to a far greater degree than shoot $\mathrm{K}$ concentrations.

Several mechanisms are known to play a role in the $\mathrm{P}$ regulation of AMF colonization, including mediation through 
hormones, $\mathrm{P}$ transporters, microRNAs, and sucrose transport to roots (Carbonnel and Gutjahr, 2014; Gu et al., 2011; Smith et al., 2011). Maximal expression of arbsucules in roots appears to require activation of the systemic $\mathrm{P}$ starvation response, but also must allow for locally high $\mathrm{P}$ status in AMF-colonized roots and $\mathrm{P}$ delivery via mycorrhiza-specific $\mathrm{P}$ transporters in cortical cells with arbuscules (Carbonnel and Gutjahr, 2014; Javot et al., 2007). Indeed, in split root experiments, where high $\mathrm{P}$ is provided to only one portion of the root system, AMF colonization is reduced in roots on the low $\mathrm{P}$ side even though root $\mathrm{P}$ concentrations are not increased on the low $\mathrm{P}$ side (Breuillin et al., 2010; Vierheilig et al., 2000). These findings and our results here indicate that shoot $\mathrm{P}$ levels and not root $\mathrm{P}$ levels primarily influence arbuscule regulation in roots. Our data showing that arbuscules are less responsive to high shoot $\mathrm{P}$ status when plants are exposed to high light further suggests that $\mathrm{P}$ repression of arbuscules may be less commonly expressed under typical agricultural conditions with full sunlight. Some studies that have examined how specific metabolites influence arbuscules in roots have employed low light levels (often below $300 \mu \mathrm{mol} \cdot \mathrm{m}^{-2} \cdot \mathrm{s}^{-1} P A R$ ) due, in part, to growing plants in growth chambers (Olsson et al., 2010; Schaarschmidt et al., 2007). In other studies, light levels have not been reported, making it unclear whether light conditions may have influenced those results (Breuillin et al., 2010; Herrera-Medina et al., 2007; Javot et al., 2007). It would be interesting to reevaluate such regulatory effects on arbuscules under higher light conditions.

The practical implications from this study are that during prolonged periods of cloudy weather (common in western Oregon and other cool climate grape-growing areas), grapevines will likely have lower levels of arbuscules in roots and a reduced capacity for $\mathrm{P}$ uptake. Certain canopy management practices applied in vineyards may improve overall radiation capture, but obviously not incident radiation. This suggests that growers should adjust the timing of fertilizer (especially P) applications to correspond with sunny weather to improve uptake efficiency via AMF. Certainly growers who apply $\mathrm{P}$ to the foliage of grapevines should avoid this practice during periods of cloudy weather, as the combination of high shoot $\mathrm{P}$ and low light will suppress arbuscules and potentially reduce other benefits from AMF.

\section{Literature Cited}

Alexander, T., R. Toth, R. Meier, and D.C. Weber. 1989. Dynamics of arbuscule development and degeneration in onion, bean, and tomato with reference to vesicular-arbuscular mycorrhizae in grasses. Can. J. Bot. 67:2505-2513.

Baier, M.C., M. Keck, V. Gödde, K. Niehaus, H. Küster, and N. Hohnjec. 2010. Knockdown of the symbiotic sucrose synthase MtSucS1 affects arbuscule maturation and maintenance in mycorrhizal roots of Medicago truncatula. Plant Physiol. 152:1000-1014.

Blee, K.A. and A.J. Anderson. 2002. Transcripts for genes encoding soluble acid invertase and sucrose synthase accumulate in root tip and cortical cells containing mycorrhizal arbuscules. Plant Mol. Biol. 50:197-211.

Bonneau, L., S. Huguet, D. Wipf, N. Pauly, and H.N. Truong. 2013. Combined phosphate and nitrogen limitation generates a nutrient stress transcriptome favorable for arbuscular mycorrhizal symbiosis in Medicago truncatula. New Phtyol. 199:188-202.

Breuillin, F., J. Schramm, M. Hajirezaei, A. Ahkami, P. Favre, U. Druege, B. Hause, M. Bucher, T. Kretzschmar, E. Bossolini, C. Kuhlemeier, E. Martinoia, P. Franken, U. Scholz, and D. Reinhardt. 2010.
Phosphate systemically inhibits development of arbuscular mycorrhiza in Petunia hybrid and represses genes involved in mycorrhizal functioning. Plant J. 64:1002-1017.

Carbonnel, S. and C. Gutjahr. 2014. Control of arbuscular mycorrhiza development by nutrient signals. Front. Plant Sci. 5:462.

Chapin, F.S., III and K. Van Cleve. 1989. Approaches to studying nutrient uptake, use, and loss in plants, p. 185-207. In: R.W. Pearcy, J. Ehleringer, H.A. Mooney, and P.W. Rundel (eds.). Plant physiological ecology, field methods and instrumentation. Chapman and Hall, New York, NY.

Daft, M.J. and A.A. El-Giahmi. 1978. Effect of arbuscular mycorrhiza on plant growth. VIII. Effects of defoliation and light on selected hosts. New Phytol. 80:365-372.

Fellbaum, C.R., J.A. Mensah, A.J. Cloos, G.E. Strahan, P.E. Pfeffer, E.T. Kiers, and H. Bücking. 2014. Fungal nutrient allocation in common mycorrhizal networks is regulated by the carbon source strength of individual host plants. New Phtyol. 203:646-656.

Gaude, N., S. Bortfeld, N. Duensing, M. Lohse, and F. Krajinski. 2012. Arbuscule-containing and non-colonized cortical cells of mycorrhizal roots undergo extensive and specific reprogramming during arbuscular mycorrhizal development. Plant J. 69:510-528.

Graham, J.H., R.T. Leonard, and J.A. Menge. 1982. Interaction of light intensity and soil temperature with phosphorus inhibition of vesiculararbuscular mycorrhiza formation. New Phytol. 91:683-690.

Gu, M., A. Chen, X. Dai, W. Liu, and G. Xu. 2011. How does phosphate status influence the development of the arbuscular mycorrhizal symbiosis? Plant Signal. Behav. 6:1300-1304.

Gutjahr, C. 2014. Phytohormone signaling in arbuscular mycorrhiza development. Curr. Opin. Plant Biol. 20:26-34.

Hammer, E.C., J. Pallon, H. Wallander, and P.A. Olsson. 2011. Tit for tat? A mycorrhizal fungus accumulates phosphorus under low plant carbon availability. FEMS Microbiol. Ecol. 76:236-244.

Hammond, J.P. and P.J. White. 2011. Sugar signaling in root responses to low phosphorus availability. Plant Physiol. 156:1033-1040.

Harrison, M.J. 2005. Signalling in the arbuscular mycorrhizal symbiosis. Annu. Rev. Microbiol. 59:19-42.

Hayman, D.S. 1974. Plant growth responses to vesicular-arbuscular mycorrhiza: VI Effect of light and temperature. New Phytol. $73: 71-80$.

Herrera-Medina, M.J., S. Steinkellner, H. Vierheilig, J.A. OcampoBote, and J.M. García-Garrido. 2007. Abscisic acid determines arbuscule development and functionality in the tomato arbuscular mycorrhiza. New Phytol. 175:554-564.

Hoagland, D.R. and D.I. Arnon. 1950. The water-culture method for growing plants without soil. California Agr. Expt. Sta. Circ. 347.

Javot, H., R.V. Penmetsa, F. Breuillin, K.K. Bhattarai, R.D. Noar, S.K. Gomez, Q. Zhang, D.R. Cook, and M.J. Harrison. 2011. Medicago truncatula mtpt4 mutants reveal a role for nitrogen in the regulation of arbuscule degeneration in arbuscular mycorrhizal symbiosis. Plant J. 68:954-965.

Javot, H., R.V. Penmetsa, N. Terzaghi, D.R. Cook, and M.J. Harrrison. 2007. A Medicago truncatula phosphate transporter indispensable for the arbuscular mycorrhizal symbiosis. Proc. Natl. Acad. Sci. USA 104:1720-1725.

Jones, J.B. and V.W. Case. 1990. Sampling, handling, and analyzing plant tissue samples, p. 389-427. In: R.L. Westerman (ed.). Soil testing and plant analysis. 3rd ed. Soil Sci. Soc. Amer., Madison, WI. Karagiannidis, N. and N. Nikolaou. 1999. Arbuscular mycorrhizal root infection as an important factor of grapevine nutrition status. Multivariate analysis application for evaluation and characterization of the soil and leaf parameters. Agrochimica 43:151-165.

Lei, M., Y. Liu, B. Zhang, Y. Zhao, X. Wang, Y. Zhou, K.G. Ragothama, and D. Liu. 2011. Genetic and genomic evidence that sucrose is a global regulator of plant responses to phosphate starvation in Arabidopsis. Plant Physiol. 156:1116-1130.

Lin, W.-Y., T.-K. Huang, S.J. Leong, and T.-J. Chiou. 2014. Longdistance call from phosphate: Systemic regulation of phosphate starvation responses. J. Expt. Bot. 64:1817-1827. 
Liu, J.-Q., D.L. Allan, and C.P. Vance. 2010. Systemic signaling and local sensing of phosphate in common bean: Cross-talk between photosynthate and microRNA399. Mol. Plant 3:428-437.

Nagel, K.A., U. Schurr, and A. Walter. 2006. Dynamics of root growth stimulation in Nicotiana tabacum in increasing light intensity. Plant Cell Environ. 29:1936-1945.

Newman, E.I. 1966. A method of estimating the total length of root in a sample. J. Appl. Ecol. 3:139-145.

Olsson, P.A., J. Rahm, and N. Aliasgharzad. 2010. Carbon dynamics in mycorrhizal symbiosis is linked to carbon costs and phosphorus benefits. FEMS Microbiol. Ecol. 72:123-131.

Parniske, M. 2008. Arbuscular mycorrhiza: The mother of plant root endosymbioses. Nat. Rev. Microbiol. 6:763-775.

Petgen, M., A. Schropp, E. George, and V. Römheld. 1998. Einfluss unterschiedlicher nokulationstiefen mit dem arbuskulären mykorrhizapilz Glomus mosseae auf die mykorrhizierung bei reben (Vitis $s p$.) in wurzelbeobachtungskästen. Vitis 37:99-105.

Pinkerton, J.N., R.P. Schreiner, K.L. Ivors, and M.C. Vasconcelos. 2004. Effects of Mesocriconema xenoplax on Vitis vinifera and associated mycorrhizal fungi. J. Nematol. 36:193-201.

Ravnskov, S., Y. Wu, and J.H. Graham. 2003. Arbuscular mycorrhizal fungi differentially affect expression of genes coding for sucrose synthases in maize roots. New Phytol. 157:539-545.

Rennenberg, H. and C. Herschback. 2013. Phosphorus nutrition of wood plants: Many questions - few answers. Plant Biol. 15:785-788. Sanders, F.E. 1975. The effect of foliar-applied phosphate on the mycorrhizal infection of onion roots, p. 261-276. In: F.E. Sanders, B. Mosse, and P.B. Tinker (eds.). Endomycorrhizas. Academic Press, London, UK.

Schaarschmidt, S., M.C. Gonzalez, T. Roitsch, D. Strack, U. Sonnewald, and B. Hause. 2007. Regulation of arbuscular mycorrhization by carbon. The symbiotic interaction cannot be improved by increased carbon availability accomplished by root-specifically enhanced invertase activity. Plant Physiol. 143:1827-1840.

Schreiner, R.P. 2003. Mycorrhizal colonization of grapevine rootstocks under field conditions. Amer. J. Enol. Viticult. 54:143-149.

Schreiner, R.P. 2005a. Mycorrhizas and mineral acquisition in grapevines, p. 49-60. In: L.P. Christensen and D.R. Smart (eds.). Proc. Soil Environ.Vine Mineral Nutr. Symp., Amer. Soc. Enol. Viticult., Davis, CA.

Schreiner, R.P. 2005b. Spatial and temporal variation of roots, arbuscular mycorrhizal fungi, and plant and soil nutrients in a mature Pinot noir (Vitis vinifera L.) vineyard in Oregon, USA. Plant Soil 276:219-234.
Schreiner, R.P. 2007. Effects of native and nonnative arbuscular mycorrhizal fungi on growth and nutrient uptake of 'Pinot noir' (Vitis vinifera L.) in two soils with contrasting levels of phosphorus. Appl. Soil Ecol. 36:205-215.

Schreiner, R.P. 2010. Foliar sprays containing phosphorus (P) have minimal impact on 'Pinot noir' growth, P status, mycorrhizal colonization, and fruit quality. HortScience 45:815-821.

Schreiner, R.P., J. Lee, and P.A. Skinkis. 2013. N, P, and K supply to Pinot noir grapevines: Impact on vine nutrient status, growth, physiology, and yield. Amer. J. Enol. Viticult. 64:26-38.

Schreiner, R.P. and K.L. Mihara. 2009. The diversity of arbuscular mycorrhizal fungi amplified from grapevine roots (Vitis vinifera L.) in Oregon vineyards is seasonally stable and influenced by soil and vine age. Mycologia 101:599-611.

Schreiner, R.P. and J.N. Pinkerton. 2008. Ring nematodes (Mesocriconema xenoplax) alter root colonization and function of arbuscular mycorrhizal fungi in grape roots in a low P soil. Soil Biol. Biochem. 40:1870-1877.

Schreiner, R.P., J.N. Pinkerton, and I.A. Zasada. 2012. Delayed response to ring nematode (Mesocriconema xenoplax) feeding on grape roots linked to vine carbohydrate reserves and nematode feeding pressure. Soil Biol. Biochem. 45:89-97.

Shi, G., Y. Liu, N. Collins-Johnson, P. Olsson, L. Mao, G. Cheng, S. Jiang, L. An, G. Du, and H. Feng. 2014. Interactive influence of light intensity and soil fertility on root-associated arbuscular mycorrhizal fungi. Plant Soil 378:173-188.

Smith, S., I. Jakobsen, M. Grønlund, and F.A. Smith. 2011. Roles of arbuscular mycorrhizas in plant phosphorus nutrition: Interactions between pathways of phosphorus uptake in arbuscular mycorrhizal roots have important implications for understanding and manipulating plant phosphorus acquisition. Plant Physiol. 156:1050-1057.

Smith, S. and D. Read. 2008. Mycorrhizal symbiosis, 3rd ed. Academic Press, New York, NY.

Son, C.L. and S.E. Smith. 1988. Mycorrhizal growth responses: Interactions between photon irradiance and phosphorus nutrition. New Phytol. 108:305-314.

Tamayo, E., T. Gómez-Gallego, C. Azcón-Aguilar, and N. Ferrol. 2014. Genome-wide analysis of copper, iron and zinc transporters in the arbuscular mycorrhizal fungus Rhizophagus irregularis. Front. Plant Sci. 5:547.

Vierheilig, H., W. Maier, U. Wyss, J. Samson, D. Strack, and Y. Piche. 2000. Cyclohexenone derivative- and phosphate-levels in split root systems and their role in the systemic suppression of mycorrhization in precolonized barley plants. J. Plant Physiol. 157:593-599. 